TECHNICAL PROGRESS REPORT NUMBER 40972R06

FOR QUARTER: April 1 - June 30, 2002

\title{
Development of Pressurized Circulating Fluidized Bed \\ Partial Gasification Module (PGM)
}

DOE Contract No: DE-FC26-00NT40972

Issued: July 10, 2002

Foster Wheeler Development Corporation

12 Peach Tree Hill Road

Livingston, NJ 07039 
"This report was prepared as an account of work sponsored by an agency of the United States Government. Neither the United States Government nor any agency thereof, nor any of their employees, makes any warranty, express or implied, or assumes any legal liability or responsibility for the accuracy, completeness, or usefulness of any information, apparatus, product, or process disclosed, or represents that its use would not infringe upon privately owned rights. Reference herein to any specific commercial product, process, or service by trade name, trademark, manufacturer, or otherwise does not necessarily constitute or imply its endorsement by the United States Government or any agency thereof. The views and opinions of authors expressed herein do not necessarily state or reflect those of the United States Government or any agency thereof." 


\section{Abstract}

Foster Wheeler Power Group, Inc. is working under US Department of Energy contract No. DE-FC26-00NT40972 to develop a partial gasification module (PGM) that represents a critical element of several potential coal-fired Vision 21 plants. When utilized for electrical power generation, these plants will operate with efficiencies greater than $60 \%$ and produce near zero emissions of traditional stack gas pollutants.

The new process partially gasifies coal at elevated pressure producing a coal-derived syngas and a char residue. The syngas can be used to fuel the most advanced power producing equipment such as solid oxide fuel cells or gas turbines, or processed to produce clean liquid fuels or chemicals for industrial users. The char residue is not wasted; it can also be used to generate electricity by fueling boilers that drive the most advanced ultra-supercritical pressure steam turbines.

The amount of syngas and char produced by the PGM can be tailored to fit the production objectives of the overall plant, i.e., power generation, clean liquid fuel production, chemicals production, etc. Hence, PGM is a robust building bock that offers all the advantages of coal gasification but in a more user-friendly form; it is also fuel flexible in that it can use alternative fuels such as biomass, sewerage sludge, etc.

This report describes the work performed during the April 1 - June 30, 2002 time period. 


\section{Table of Contents}

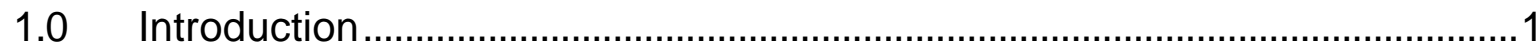

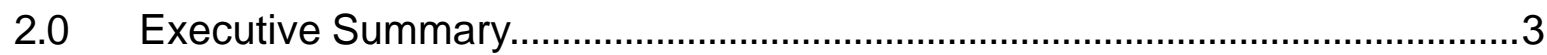

3.0 Proposed Program.....................................................................................

4.0 Progress for April-June 2002 Time Period.....................................................

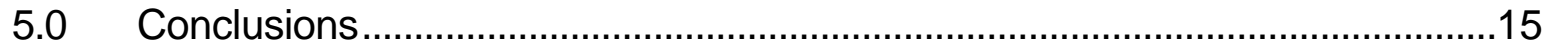

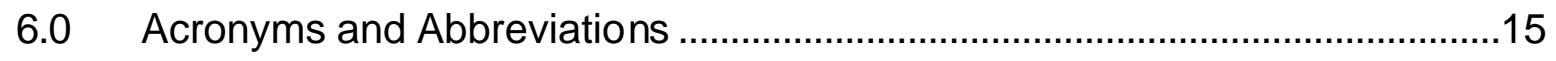

\section{Figures}

$1 \quad$ Vision 21 Modules - Enabling Technologies.................................................

$2 \quad$ Partial Gasifier Module Experimental Test Unit .............................................

$3 \quad$ Simplified Schematic of PGM with ACFB Boiler ........................................... 7

$4 \quad$ Simplified Schematic of PGM with PCFB Boiler............................................

5 Vision 21 Partial Gasifier Module Schedule ...............................................14

\section{$\underline{\text { Tables }}$}

1 Effect of Char Combustor Type on PGM Vision 21 Plant Performance........10

2 Estimated Plant Parasitic Losses (MWe) ...................................................11

$3 \quad$ Typical Compositions of Fuels Tested...........................................................13 


\subsection{Introduction}

Foster Wheeler Development Corporation is working under DOE contract No. DEFC26-00NT40972 to develop a partial gasification module (PGM) that represents a critical element of several potential coal-fired Vision 21 plants. When utilized for electrical power generation, these plants will operate with efficiencies greater than $60 \%$ while producing near zero emissions of traditional stack gas pollutants.

The new process partially gasifies coal at elevated pressure producing a coal-derived syngas and a char residue. The syngas can be used to fuel the most advanced power producing equipment such as solid oxide fuel cells or gas turbines or processed to produce clean liquid fuels or chemicals for industrial users. The char residue is not wasted; it can also be used to generate electricity by fueling boilers that drive the most advanced ultra-supercritical pressure steam turbines.

The unique aspect of the process is that it utilizes a pressurized circulating fluidized bed partial gasifier and does not attempt to consume the coal in a single step. To convert all the coal to syngas in a single step requires extremely high temperatures $(\sim 2500$ to $2800 \mathrm{~F})$ that melt and vaporize the coal and essentially drive all coal ash contaminants into the syngas. Since these contaminants can be corrosive to power generating equipment, the syngas must be cooled to near room temperature to enable a series of chemical processes to clean the syngas. Foster Wheeler's process operates at much lower temperatures that control/minimize the release of contaminants; this eliminates/ minimizes the need for the expensive, complicated syngas heat exchangers and chemical cleanup systems typical of high temperature gasification. By performing the gasification in a circulating bed, a significant amount of syngas can still be produced despite the reduced temperature and the circulating bed allows easy scale up to large size plants. Rather than air, it can also operate with oxygen to facilitate sequestration of stack gas carbon dioxide gases for a $100 \%$ reduction in greenhouse gas emissions.

The amount of syngas and char produced by the PGM can be tailored to fit the production objectives of the overall plant, i.e., power generation, clean liquid fuel production, chemicals production, etc. Hence, PGM is a robust building block that offers all the advantages of coal gasification but in a more user friendly form; it is also fuel flexible in that it can use alternative fuels such as biomass, sewerage sludge, etc.

The PGM consists of a pressurized circulating fluidized bed (PCFB) reactor together with a recycle cyclone and a particulate removing barrier filter. Coal, air, steam, and possibly sand are fed to the bottom of the PCFB reactor and establish a relatively dense bed of coal/char in the bottom section. As these constituents react, a hot syngas is produced which conveys the solids residue vertically up through the reactor and into the recycle cyclone. Solids elutriated from the dense bed and contained in the syngas are collected in the cyclone and drain via a dipleg back to the dense bed 
at the bottom of the PCFB reactor. This recycle loop of hot solids acts as a thermal flywheel and promotes efficient solid-gas chemical reaction.

Left untreated the syngas will contain tar/oil vapors, alkali vapors, and hydrogen sulfide at levels dependent on PGM operating conditions and fuels. The downstream users of the syngas will dictate a tolerance level for each of these gas constituents. If the users can tolerate both tar vapors and hydrogen sulfide, the syngas can be cooled to a level that condenses the alkali vapors on the particulate being removed by the barrier filter. Although this is a simple solution to an alkali problem, syngas cooling typically lowers the plant efficiency. When efficiency is to be maximized, as in the case of Vision 21 plants, the clean up can be done hot/without syngas cooling. In this case, lime based sorbents can be fed to the PCFB reactor along with the coal to catalytically enhance tar cracking and react with the hydrogen sulfide to capture the sulfur as calcium sulfide. Depending upon sorbent feed rates and gas residence times, the hydrogen sulfide can be reduced to near equilibrium levels which for high sulfur fuels (>3\% sulfur) amounts to 95 to $98 \%$ sulfur capture. Alkali levels can be brought to gas turbine acceptable levels by injecting finely ground getter material such as emathlite or bauxite into the syngas downstream of the recycle cyclone. The fine particulate that escapes the recycle cyclone together with the injected alkali getter material are carried into the barrier filter by the syngas. As the syngas flows through the porous filter elements, the particulate collects on the outside of the elements and forms a permeable dust cake that ensuing syngas must pass through. The getter absorbs the alkali vapors as the syngas flows to the filter and passes through the filter dust cake. As the dust cake thickness increases, the filter pressure drop increases. Upon reaching a predetermined pressure drop, the dust cake is blown off the element by a back pulse of a clean high-pressure gas such as nitrogen injected into the clean side of the element. The dislodged dust cake falls to the bottom of the filter vessel and drains from the unit. If even higher sulfur capture efficiencies are desired, a second more reactive sorbent can be injected into the syngas for enhanced filter cake sulfur capture. Although the barrier filter is provided to reduce syngas particulate loadings to less than $1 \mathrm{ppm}$, it can also serve as a reactor in that its filter cake can be used for alkali vapor removal and sulfur capture. The char-sorbent-getter residue generated in the PGM drains continuously from the filter along with an intermittent PCFB reactor bed drain for transfer to the char combustor.

The proposed partial gasifier module (PGM) represents a building block of the Vision 21 program, which can be connected with a variety of additional modules to form complete Vision 21 plants (Figure 1). The PGM represents an "enabling" technology within the Vision 21 framework in that it can serve as a central processing unit for converting the raw fuel (coal, coke, biomass, or other opportunity fuels) into useful by-products (electricity, steam, chemicals, or transportation fuels). 


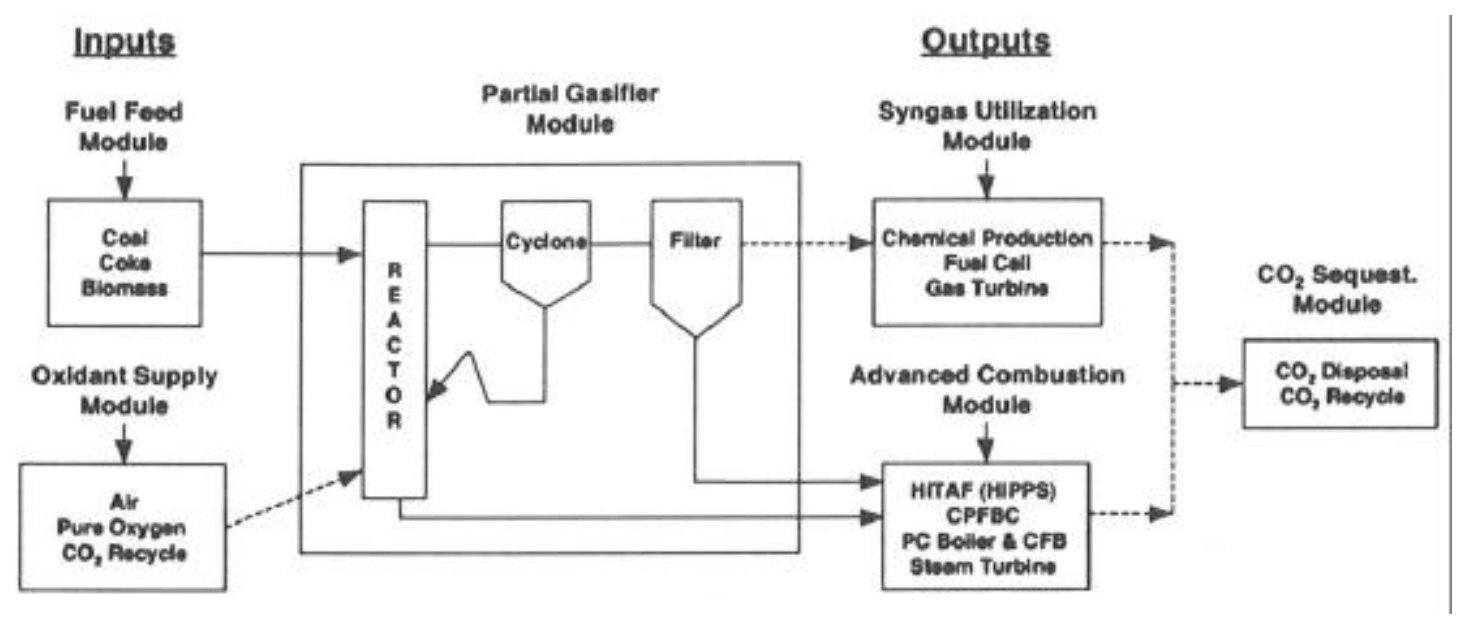

Fig. 1 Vision 21 Modules - Enabling Technologies

\subsection{Executive Summary}

FW's partial gasification tests in an air blown pressurized circulating fluidized bed gasifier pilot plant have been successfully completed. Under this test program, five different coals, petroleum coke, and sawdust were gasified and the effects of oxygen and $\mathrm{CO}_{2}$ enrichment of the fluidizing air studied. Although detailed data analysis is not expected to begin until July 2002, testing has shown that the PCFB gasifier:

a. can gasify a wide variety of fuels;

b. can handle highly caking coals without agglomeration problems;

c. can operate in a co-firing biomass-coal mode;

d. can operate with oxygen and carbon dioxide enriched air;

e. can use porous metal filters to filter particulate without tar/oil blinding;

f. char residue can be easily handled.

ASPEN computer model simulations of PGM Vision 21 plants using three different types of combustors, e.g., ACFB, PCFB, and HITAF to burn the char residue from the PGM have shown that all can exceed the Vision 21 efficiency goal.

\subsection{Proposed Program}

FW possess a coal-fired PCFB pilot plant at its John Blizard Research Center in Livingston, NJ. The facility can be operated in either a combustion or gasification mode with a gross heat input of up to 12 million Btu/hr. To support the Vision 21 program, the facility will be operated in the gasification mode with the focal point being the PCFB reactor with its recycle cyclone dipleg and loop seal and a barrier filter. These three components form the PGM shown in Fig. 2 and a syngas cooler can be installed to control the filter inlet temperature. 


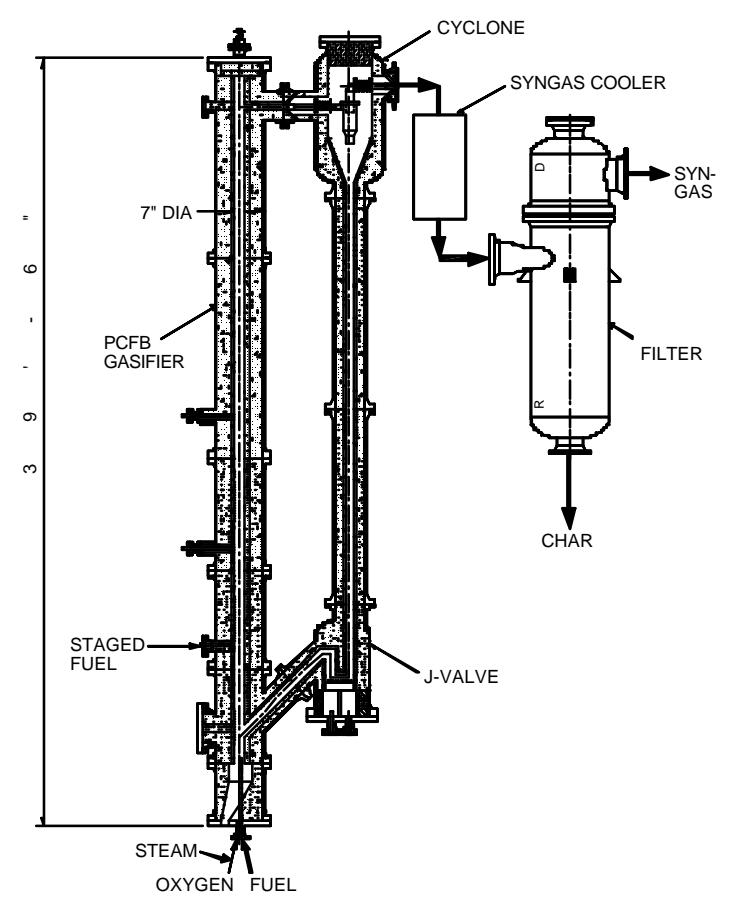

Fig. 2 Partial Gasifier Module Experimental Test Unit

The PCFB reactor is a 30" OD x 39'-6" tall vessel that is refractory lined to a 7" ID. Two lock hopper feed trains operating in parallel bring coal and sorbent to process pressure and feed the materials into a common line that injects the material into the reactor. The coal and sorbent are blown into the unit by air via a vertical 1" Sch 80 pipe located on the centerline and at the base of the unit. A 11/2" pipe concentric with the feed pipe admits the balance of the process air together with steam. A relatively dense bed of coal, char, and sorbent form at the base of the unit. Syngas, together with entrained bed particulate matter, flow vertically up the unit at velocities ranging from 12 to $15 \mathrm{ft} / \mathrm{sec}$ and exit via a 4" ID radial nozzle 34'-10" above the top of the feed pipe. A recycle cyclone removes larger size particles from the syngas and returns them to the base of the unit via a dipleg and loop seal. The partially cleaned syngas passes through a cooler, a second stage cyclone, and enters a barrier filter vessel for removal of the remaining particulate. The filter can contain up to twenty-two $23 / 8$ " OD x 60" long candles all hung at one elevation from a metallic horizontal tube sheet. The syngas cooler is designed to yield filter inlet temperatures ranging from 650 to $800 \mathrm{EF}$ to allow operation with porous metal iron aluminide candles. The char-sorbent residue generated in the PGM is drained from the bottom of the PCFB reactor via a $2 \frac{1}{2}$ " wide annulus around the $1 \frac{1}{2} 2^{\prime \prime}$ air supply pipe. The draining material enters a holding section where counter flowing nitrogen cools the material as a packed bed to approximately 500EF. A lock hopper provided under the PCFB reactor and under the filter collects and depressures the material in batches for disposal.

Under the Vision 21 program, the PGM will be operated at varying conditions to determine syngas and char yields, heating values, and compositions when operating with: 
1. alternative fuels, e.g., coke and coal-biomass cofiring

2. oxygen-enriched air

The Vision 21 effort is divided into the following five tasks:

Task 1 - Research and Development - Included in this effort are characterization of feedstocks to be tested, material evaluations to determine process induced corrosion rates, computer modeling of the PGM, and updates of possible Vision 21 plant configurations.

Task 2 - Engineering Design - Included in this task is the design of all modifications that must be made to and the procurement of materials that must be incorporated in the existing pilot plant to facilitate the Vision 21 test program.

Task 3 - Construction - This task covers the construction of all Task 2 changes/ modifications.

Task 4 - Testing - Included in this effort are parametric tests and data analyses dealing with alternate feedstocks and oxygen-enriched air plus evaluations of Stamet feed pump and filter performance.

Task 5 - Project Management - Conduct all activities needed to insure that project objectives are met on time and within budget; issue all cost and progress reports and a final report documenting the results of all test activities.

\subsection{Progress for April - June, 2002, Time Period}

Task 1 - Research and Development

In a commercial scale Vision 21 plant, the char produced by the PGM can be combusted in an atmospheric pressure circulating fluidized bed (ACFB) boiler, a PCFB boiler, or a pulverized coal type high temperature air heater/boiler (HITAF). With the ACFB boiler and HITAF both running at atmospheric pressure, the unused oxygen remaining in the gas turbine exhaust is used as the oxidant for these units in a hot windbox arrangement.

Foster Wheeler has prepared with its own R\&D funds an ASPEN model of the Gasification Fluidized Bed Combined Cycle Plant it is proposing for demonstration under Round V of the Clean Coal Demonstration Plant Program. Since this already working model incorporates a PGM coupled with a gas turbine and a hot windbox ACFB char burning boiler, rather than start from scratch, it was decided to use it to identify the performance characteristics of each of the above three different Vision 21 plant configurations. The model was modified to incorporate a solid oxide fuel cell (SOFC) together with Vision 21 gas turbine and steam turbine data, and this became the platform for three new Vision 21 plant models. The first used the hot windbox 
ACFB boiler, the second replaced the ACFB with a hot windbox HITAF, and in the third a PCFB boiler was used to burn the char.

Figures 3 and 4 are simplified schematics of the PGM coupled with ACFB and PCFB boilers respectively; for the HITAF case the ACFB boiler shown in Figure 3 would be replaced by a pulverized coal boiler configuration. The following summarizes the key component performance data incorporated in the ASPEN models of each of these plants, which were used to determine their relative performance characteristics:

ATS Gas Turbine

inlet flow: $1200 \mathrm{lb} / \mathrm{sec}$

pressure ratio: $29 / 1$

compressor polytropic efficiency: $91 \%$

combustor outlet: $2900 \mathrm{~F}$

expander issentropic efficiency: $92 \%$ adiabatic

shaft power to electric power: $98 \%$

Steam Turbine

$6500 / 1300 / 1300 / 1300 / 21 / 2 " H g$

Partial Gasifier

Illinois \#6 coal

outlet temperature: 1900F

syngas cooler/ceramic candle filter outlet temperature: $1700 \mathrm{~F}$

\section{Solid Oxide Fuel Cell}

syngas inlet temperature: $1200 \mathrm{~F}$ (cooled from $1700 \mathrm{~F}$ to allow cleanup of this coal gas)

air inlet temperature: $\approx 1000 \mathrm{~F}$

hydrogen conversion: $85 \%$

converted $\mathrm{H} 2$ energy to electricity: $53 \%$

converted $\mathrm{H} 2$ energy to steam cycle: $44 \%$

converted $\mathrm{H} 2$ energy loss: $3 \%$

\section{Gas Turbine Combustor}

syngas inlet temperature from gasifier candle filter: $1700 \mathrm{~F}$

air inlet temperature from air cooled tubes: $1520 \mathrm{~F}$ or $1800 \mathrm{~F}$

char combustion efficiency: $99 \%$ 


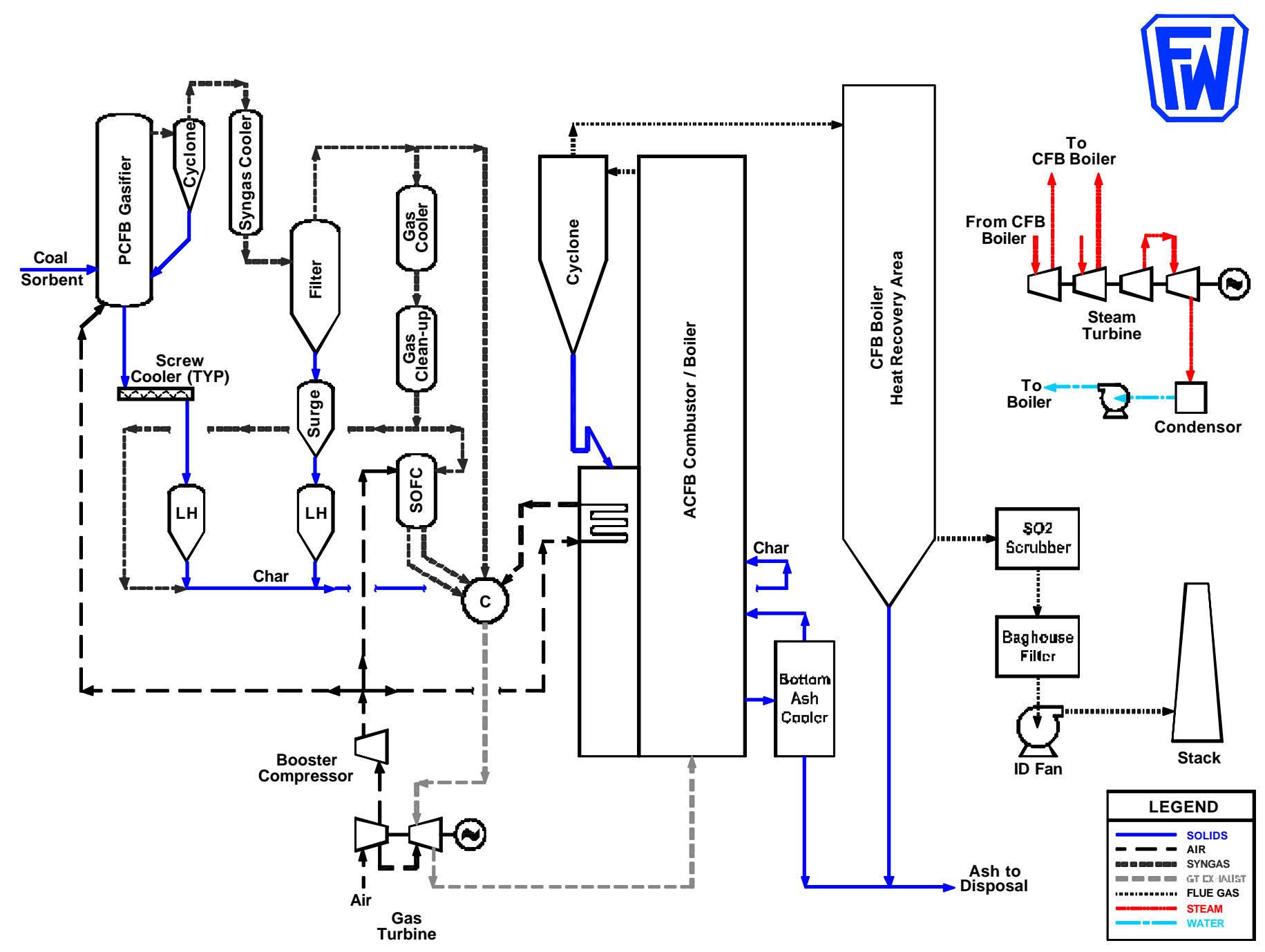

Fig. 3 Simplified Schematic of PGM with ACFB Boiler 


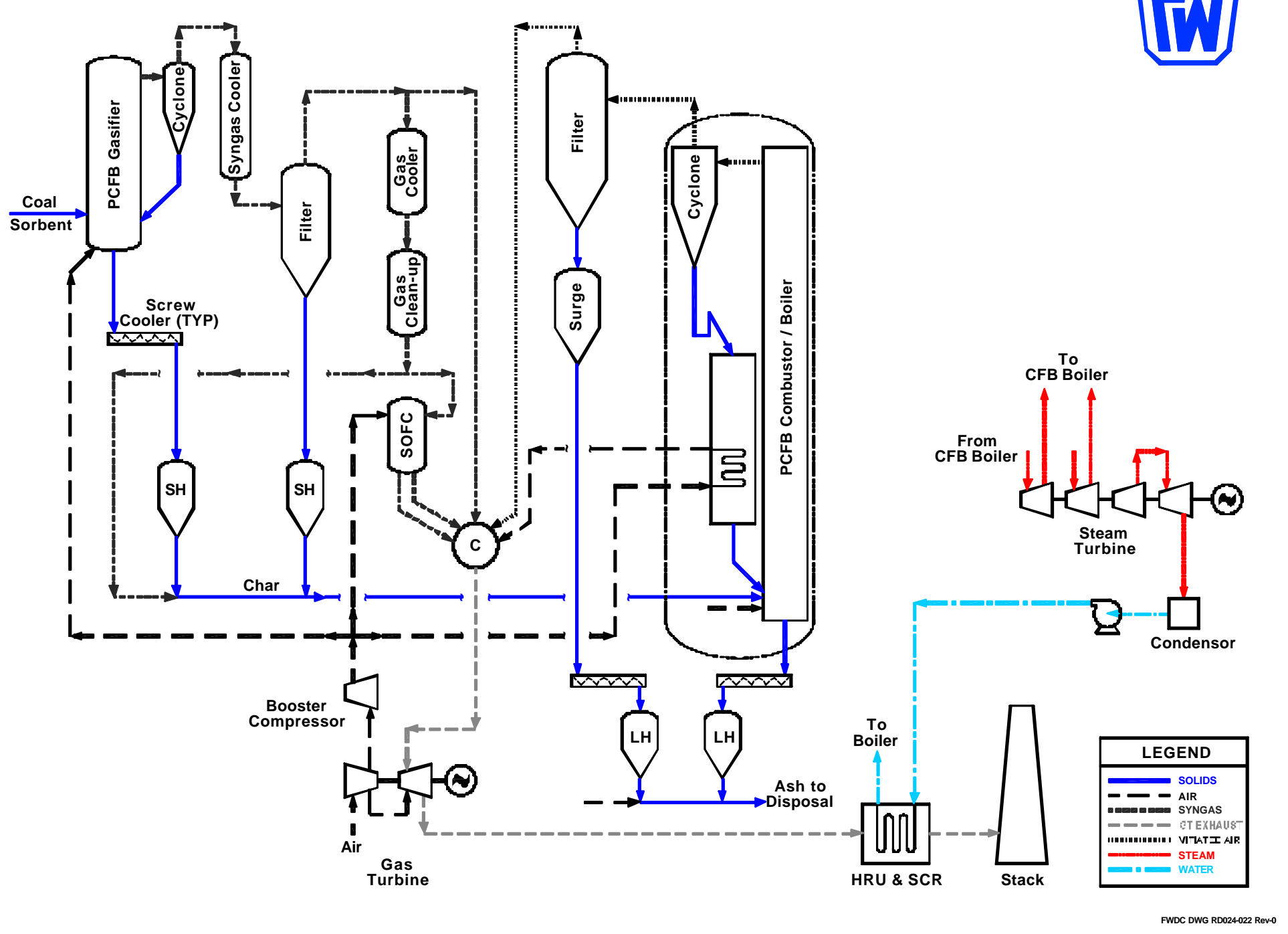

Fig. 4 Simplified Schematic of PGM with PCFB Boiler 
Table 1 tabulates preliminary performance data for each of these plants in an attempted "apples-to-apples" comparison of their capabilities at two different SOFC operating temperatures, the first at about $1900 \mathrm{~F}$ and the second at about 2100 to 2200F. Rather than assign a fixed percentage of the plant gross power output for auxiliary losses, we have attempted a more accurate determination of losses by scaling up data given in EPRI Report GS-6621 entitled, "Assessment of Circulating Atmospheric Fluid-Bed Combustion Technology for Utility Applications." With Table 2 estimated losses incorporated in Table 1, we see that at the lower SOFC temperature the plant higher heating value (HHV) efficiencies range from 59.8 to 60.2 , while the higher SOFC temperature increases the efficiency range from 60.1 to $60.8 \%$. The following is observed:

a. since the gas turbine exhaust serves as the oxidant for the ACFB and HITAF plants, the gas turbine cooling air flow is used to support additional char combustion in these units. As a result, these plants operate with a higher coal flow rate and produce more power than the PCFB plants.

b. increasing the SOFC operating temperature increases the effectiveness of the water gas shift reaction thereby increasing the hydrogen content of the syngas. As a result, higher SOFC temperatures require less $1200 \mathrm{~F}$ syngas which discharges less heat to the steam cycle and the steam turbine size decreases as SOFC power increases.

c. with the HITAF combustion furnace temperature exceeding $3000 \mathrm{~F}$, the gas turbine (GT) combustor air can be heated to $1800 \mathrm{~F}$, whereas the ACFB and PCFB 1600F combustion temperatures limit the air temperature to about 1520F. As a result, HITAF transfers a greater amount of char combustion heat release to the gas turbine cycle and so its steam turbine power output is less than that of the ACFB. With the gas turbine cycle being more efficient than the steam turbine cycle, HITAF can yield a higher plant efficiency, but this advantage is almost negated by an increase in SOFC temperature where the HITAF and ACFB plant efficiencies are essentially identical at 60.6 versus $60.8 \%$. 
Table 1 Effect of Char Combustor Type on PGM Vision 21 Plant Performance

\begin{tabular}{|l|c|c|c|}
\hline Char Combustor Type & PCFB & ACFB & HITAF \\
\hline Air Flow Rate, $10^{3} \mathrm{lb} / \mathrm{hr}$ & & & \\
\hline Coal Flow Rate, $10^{3} \mathrm{lb} / \mathrm{hr}{ }^{*}$ & 4320 & 4320 & 4320 \\
\hline Gasifier Steam Flow Rate, Ib/lb of coal & 330 & 410 & 410 \\
\hline Char Flow Rate, 10 ${ }^{3} \mathrm{lb} / \mathrm{hr}$ & 0.18 & 0.18 & 0.18 \\
\hline Syngas Cooler Type & 127 & 157 & 157 \\
\hline GT Combustor Air Temp., F & Shtr & Shtr & Shtr \\
\hline Stack Gas O, Vol. \% & 1520 & 1520 & 1800 \\
\hline Stack Temp., F & 6.8 & 3.7 & 4.6 \\
\hline Fuel Cell Outlet Temp., F & 267 & 315 & 311 \\
\hline Gross Power Output, MWe & & & \\
\hline ATS Gas Turbine & 1893 & 1898 & 1846 \\
\hline SC Steam Turbine & & & \\
\hline SOFC & 312.8 & 328.3 & 340.1 \\
\hline Total & 239.1 & 303.7 & 287.1 \\
\hline Estimated & 115.1 & 204.4 & 213.1 \\
\hline Parasitic Power, MWe & 667.0 & 836.4 & 840.3 \\
\hline Net Power Output, MWe & & & \\
\hline Net Plant Efficiency (HHV), \% & 25.5 & 39.5 & 38.3 \\
\hline Fuel Cell Outlet Temp., F & 641.5 & 796.9 & 802.0 \\
\hline Gross Power Output, MWe & 59.8 & 59.8 & 60.2 \\
\hline ATS Gas Turbine & & & \\
\hline SC Steam Turbine & 2149 & 2189 & 2097 \\
\hline SOFC & & & \\
\hline Total & 314.6 & 328.3 & 340.2 \\
\hline Estimated & 232.4 & 293.7 & 279.6 \\
\hline Parasitic Power, MWe & 122.5 & 224.7 & 229.0 \\
\hline Net Power Output, MWe & 669.5 & 846.7 & 848.8 \\
\hline Net Plant Efficiency (HHV), \% & 644.3 & 808.0 & 810.5 \\
\hline & 60.1 & 60.6 & 60.8 \\
\hline
\end{tabular}


Table 2 Estimated Plant Parasitic Power Losses (MWe)

\begin{tabular}{|l|c|c|c|c|c|c|}
\hline Char Combustor Type & \multicolumn{2}{|c|}{ PCFB } & \multicolumn{2}{c|}{ ACFB } & \multicolumn{2}{c|}{ HITAF } \\
\hline & & & & & & \\
\hline Fuel Cell Outlet Temp., F & 1893 & 2149 & 1898 & 2189 & 1846 & 2097 \\
\hline Coal Handling & .0 .30 & 0.30 & 0.37 & 0.37 & 0.37 & 0.37 \\
\hline Limestone Handling & 1.32 & 1.32 & 1.64 & 1.64 & 1.64 & 1.64 \\
\hline Coal/Limestone Feeding & 1.06 & 1.06 & 1.31 & 1.31 & 1.31 & 1.31 \\
\hline Baghouse & 0 & 0 & 0.50 & 0.50 & 0.50 & 0.50 \\
\hline Ash Handling & 1.17 & 1.01 & 1.41 & 1.41 & 1.41 & 1.41 \\
\hline Fans & 0 & 0 & 10.75 & 10.75 & 10.74 & 10.74 \\
\hline Compressors $^{*}$ & 6.20 & 6.32 & 5.95 & 6.08 & 5.76 & 5.95 \\
\hline Feed Pumps* & 11.10 & 10.94 & 12.93 & 12.06 & 12.06 & 11.85 \\
\hline Cooling Tower \& Circ. Pump & 1.30 & 1.25 & 1.64 & 1.58 & 1.55 & 1.51 \\
\hline Miscellaneous & 3.00 & 3.00 & 3.00 & 3.00 & 3.00 & 3.00 \\
\hline Total & 25.45 & 25.20 & 39.50 & 38.70 & 38.34 & 38.28 \\
\hline
\end{tabular}

*calculated by ASPEN; all others scaled from EPRI Report GS6621

The three Vision 21 plants utilize advanced technologies that require extensive R\&D development with earliest deployment being year 2015 or later. After refining the Table 1 performance data, a sensitivity analysis will next be conducted to determine what plant efficiencies will result if less severe/more commercially available operating conditions are selected for the plant's various components. The variables to be studied will be discussed with the DOE and eventually a conceptual design and economic analysis prepared for that plant arrangement deemed best for near term deployment.

Task 2 - Engineering Design

This task was completed in a prior reporting period

Task3 - Construction

This task was completed in a prior reporting period

Task 4 - Testing

PGM pilot plant testing was completed in January 2002, and laboratory analyses of solids and gas samples collected during the program continued through June. A total of 116 syngas bag samples and 95 solid samples have been analyzed. After inputting this data into spreadsheets, detailed analysis will begin in July aimed at developing energy, mass, and atom balances for each of the 22 test points that were completed. Table 3 identifies typical compositions of the fuels tested in the pilot plant, and based on preliminary analyses of syngas compositions reported by a mass 
spectrometer installed downstream of the porous metal filter, the PCFB partial gasifier yielded the following ranges of carbon conversions:

$\begin{array}{ll}\text { Subbituminous coal: } & 95 \text { to } 98 \% \\ \text { Bituminous coals: } & 48 \text { to } 75 \% \\ \text { Petroleum coke: } & 55 \text { to } 59 \%\end{array}$

FW has a proprietary gasification computer model for predicting syngas yields, compositions, heating values, etc. The above conversions are in agreement with predictions made by this model and are consistent with Vision 21 plant predictions. As a result, our Vision 21 test program has been very successful in that:

a. it has confirmed commercial plant predictions;

b. it has demonstrated that a PCFB can gasify a wide variety of fuels ;

c. it can handle highly caking coals without agglomeration problems;

d. it can operate in a co-firing biomass-coal mode;

e. it can operate with oxygen and carbon dioxide enriched air;

f. porous metal filters can be used to filter particulate without tar/oil blinding;

g. the char residue produced by the PCFB can be easily handled. 
Table 3 Typical Composition of Fuels Tested

\begin{tabular}{|c|c|c|c|c|c|c|c|}
\hline $\begin{array}{l}\text { Mine } \\
\text { Location }\end{array}$ & $\begin{array}{l}\text { Eagle Butte } \\
\text { WY }\end{array}$ & $\begin{array}{c}\text { West Elk } \\
\text { CO }\end{array}$ & $\begin{array}{l}\text { Jones Fork } \\
\text { KY }\end{array}$ & $\begin{array}{c}\text { Dilworth } \\
\text { PA }\end{array}$ & $\begin{array}{c}\text { Buchanan } \\
\text { PA }\end{array}$ & -- & -- \\
\hline Fuel & Subbitum. & Bitum. & Bitum. & Bitum. & Bitum. & Pet Coke & Sawdust \\
\hline \multicolumn{8}{|l|}{$\begin{array}{l}\text { Proximate, } \\
\text { Wt \% AR }\end{array}$} \\
\hline Moisture & 23.57 & 3.55 & 6.83 & 7.50 & 7.12 & 1.84 & 4.28 \\
\hline Volatiles & 31.50 & 37.11 & 35.74 & 33.41 & 19.05 & 11.14 & 76.79 \\
\hline Fixed Carbon & 39.23 & 51.53 & 49.77 & 51.63 & 67.93 & 84.12 & 16.55 \\
\hline Ash & 5.70 & 7.81 & 7.66 & 7.46 & 5.90 & 2.90 & 2.38 \\
\hline \multicolumn{8}{|l|}{ Ultimate, } \\
\hline Wt \% AR & & & & & & & \\
\hline Carbon & 54.09 & 73.22 & 70.93 & 72.96 & 79.44 & 88.03 & 47.64 \\
\hline Hydrogen & 3.45 & 5.16 & 4.65 & 4.67 & 3.85 & 3.73 & 5.42 \\
\hline Nitrogen & 0.72 & 1.51 & 1.44 & 1.45 & 1.08 & 1.28 & 0.44 \\
\hline Chlorine & 0.00 & 0.05 & 0.14 & 0.12 & 0.17 & 0.00 & 0.00 \\
\hline Sulfur & 0.29 & 0.64 & 1.06 & 1.41 & 0.74 & 2.16 & 0.03 \\
\hline Ash & 5.70 & 7.81 & 7.66 & 7.46 & 5.90 & 2.90 & 2.38 \\
\hline Moisture & 23.57 & 3.55 & 6.83 & 7.50 & 7.13 & 1.84 & 4.28 \\
\hline Oxygen & 12.18 & 8.06 & 7.29 & 4.43 & 1.69 & 0.06 & 39.81 \\
\hline $\mathrm{HHV}, \mathrm{Btu} / \mathrm{lb}$ & 9070 & 12899 & 12798 & 12977 & 13760 & 14793 & 8238 \\
\hline FSI & --- & $11 / 2$ & $31 / 2$ & 8 & 8 & --. & --- \\
\hline
\end{tabular}

\section{Task 5 - Project Management}

The project is proceeding in accordance with the Figure 5 schedule and as such will be completed on time and within budget. 


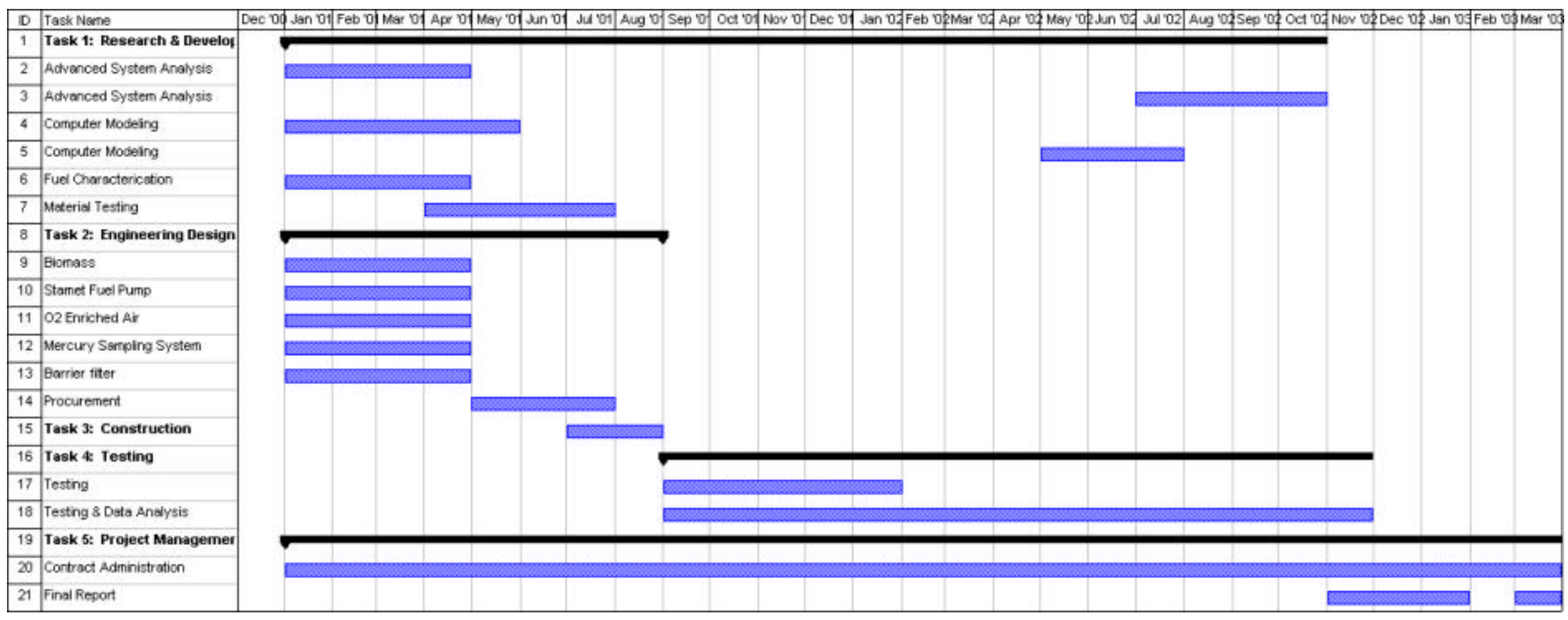

Fig. 5 Vision 21 Partial Gasification Module Schedule 


\section{$5.0 \quad$ Conclusions}

The performance of FW's PGM Vision 21 plant was determined with three different char combustor configurations, e.g., ACFB vs. PCFB vs. HITAF. All three char combustor configurations yielded plant efficiencies that met/exceeded the Vision 21 goal of $60 \%$. Although the HITAF configuration yielded the highest efficiency, its advantage diminished with increasing fuel cell temperature and in the extreme ACFB and HITAF char combustors yielded similar plant efficiencies.

\subsection{Acronyms and Abbreviations}

ACFM Atmospheric Pressure Circulating Fluidized Bed

ATS Advanced Turbine System

DOE U.S. Department of Energy

FW Foster Wheeler Power Group, Inc.

HITAF High-Temperature Air Heater

PCFB Pressurized Circulating Fluidized Bed

PGM Partial Gasification Module

SOFC Solid Oxide Fuel Cell 